\title{
SIGNIFICANT OTHERS
}

\section{Theo van Boven}

\author{
Roland Moerland \& Hans Nelen
}

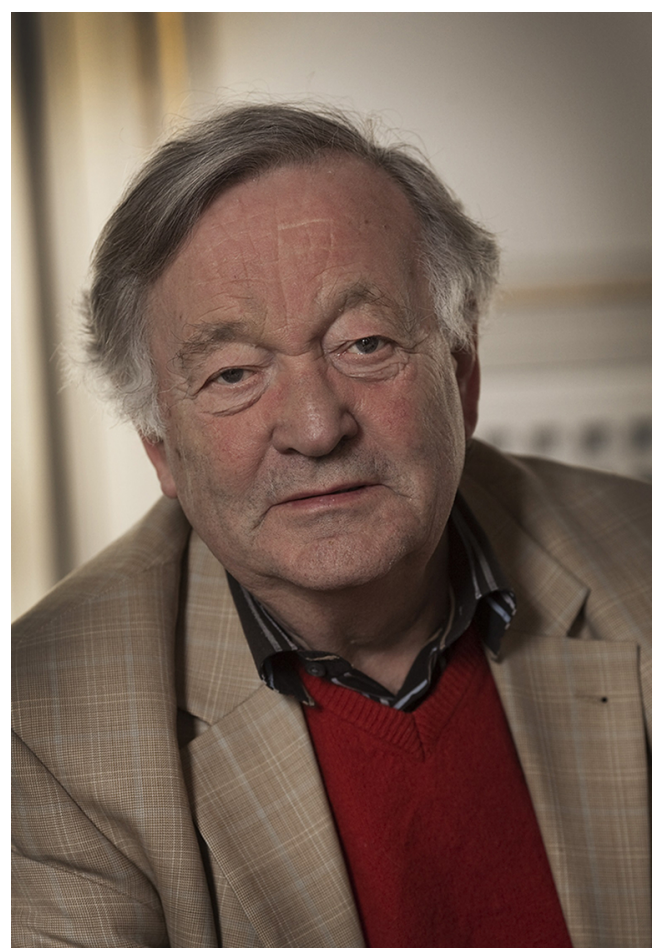

Hij ging negentien jaar geleden met emeritaat, maar Theo van Boven is in binnenen buitenland nog steeds een graag geziene gast op bijeenkomsten gewijd aan mensenrechten. De eretitel 'significant other' past hem als geen ander. Hij was de eerste die zich in zijn rol van directeur van de Human Rights Division van de Verenigde Naties openlijk uitsprak tegen de grove mensenrechtenschendingen in Chili, Uruguay, de Filippijnen, Argentinië en tal van andere landen. Die aan de basis stond van relevante working groups binnen de VN (onder andere over slavernij en de rechten van indigenous populations). Die zich niet beperkte tot bestudering van rapporten over mensenrechtenschendingen, maar zelf op onderzoek uitging en in gesprek ging met slachtoffers en hun familieleden - zoals in Argentinië met de 'Dwaze moeders' op het Plaza de Mayo. Die bezoeken bracht aan gevangenissen en daar net zo lang doordramde, totdat hij toegang kreeg tot de vertrekken waar de gevangenen werden gemarteld. Die zich niet de mond liet snoeren door de Argen- 
tijnse ambassadeur bij de Verenigde Naties in Genève, Martinèz, die zijn bijnaam de 'Butcher' onder andere dankte aan zijn agressieve manier van debatteren. En die niet schroomde om de machtige VN-gezant Perez de Cuellar openlijk te bekritiseren over de halfhartige wijze waarop de laatste een onderzoek had afgewikkeld naar mensenrechtenschendingen in Uruguay. Het laatste zou Van Boven overigens persoonlijk nog duur komen te staan, want toen de genoemde Perez de Cuellar enkele jaren later met steun van de Verenigde Staten werd verkozen tot secretaris-generaal van de VN ontdeed hij zich zo snel mogelijk van die 'lastige' directeur.

Wij twijfelden geen moment. Een man die zijn leven lang is opgekomen voor onderdrukten en slachtoffers en als geen ander weet hoe regimes proberen mensenrechtenschendingen te camoufleren en te ontkennen, mocht in een special over de taal van ontkenning niet ontbreken. Bijkomend voordeel voor de interviewers, beiden verbonden aan de Universiteit Maastricht, was dat Theo van Boven nog steeds actief is in de Limburgse hoofdstad. Daar werd hij in 1982 benoemd als hoogleraar Internationaal Recht aan de jonge rechtenfaculteit van de Rijksuniversiteit Limburg. Deze functie bleef hij tot aan zijn emeritaat in 1999 combineren met diverse functies op het gebied van Internationaal Publiekrecht en Mensenrechten, waaronder de functie van speciaal rapporteur voor het recht op schadeloosstelling van slachtoffers van grove schendingen van de mensenrechten (1986-1991). Na zijn emeritaat zette hij zijn werk ter verbetering van de mensenrechtensituatie in de wereld onvermoeibaar voort, onder andere als speciaal rapporteur voor marteling (2001-2004). Hij was tevens eerste griffier van het Joegoslavië Tribunaal en leidde de Nederlandse afvaardiging tijdens de conferentie in Rome met betrekking tot de oprichting van het Internationale Strafhof. Theo van Boven werd voor zijn werk onderscheiden met diverse prijzen, eredoctoraten en ridderordes.

\section{Argentinië}

'Als je in deze thematiek geïnteresseerd bent, dan ben je vast wel bekend met het werk van Stanley Cohen', zegt Theo terwijl hij binnenwandelt en Cohens boek States of Denial uit zijn tas haalt. 'Die Cohen was een interessante en aardige man. Zeer scherp en kritisch. Ik heb ooit samen met hem in de International Council on Human Rights Policy gezeten, daar ken ik hem van.' Nog voordat we hem verder over Cohen kunnen polsen, gaat Theo alweer verder en haalt hij, terwijl hij aan tafel gaat zitten, nog twee andere imposante bundels te voorschijn:

'Begin jaren 1980 is er na veel moeite door de VN een werkgroep opgericht over verdwijningen. Het land dat het meeste dwars lag en ons het leven zuur maakte was Argentinië. Die werkgroep bestaat nog steeds en is nog steeds actief. Ze hebben me, toen ik weg moest bij de VN, de eerste twee jaar van de rapportages cadeau gedaan. Ter voorbereiding van dit gesprek heb ik dat nog eens doorgenomen. Als het gaat om de kwestie van de taal en taalgebruik, dan komt daaruit wel een aantal zaken naar voren. De werkgroep legde allerlei 
zaken voor aan de Argentijnen en daar hebben ze dus in een aantal brieven en verklaringen op gereageerd. Uit deze reacties blijkt dat ze een heel patroon van 'denial' hebben opgezet. [...] Wat mij nog opviel: de Argentijnen waren het meest subtiel zou ik zeggen in het uitzetten van een patroon van denial. Ik vond het bijna duivelachtig ... hoe ze dat gedaan hebben. [...] Ik heb Argentinië genomen omdat het qua affiniteit, inkleding en redenering het meest sophisticated was. [...] Ik heb mij alleen beperkt tot wat Argentinië officieel te berde bracht en hoe ze dat onder woorden brachten. Ik heb me gebaseerd op deze twee eerste rapporten van de werkgroep "verdwenen personen". Ik heb ook een rol gespeeld in de hele opzet van die werkgroep. In gesprekken die daar waren met de Argentijnse autoriteiten werd ik dus ook als een soort van subversief gevaar betiteld. Ze hebben tenslotte hun zin gekregen; dat mijn contract niet verlengd werd.'

Naast het boek van Cohen en de rapportages van de VN-werkgroep legt Theo uiteindelijk ook de gedetailleerde aantekeningen die hij heeft gemaakt op tafel. De materie inspireert hem en hij heeft zich goed voorbereid. Het lijkt ons daarom verstandig om Theo's aanzet te volgen en we besluiten het gesprek op Argentinië toe te spitsen. We grijpen terug op Cohen en het onderscheid dat hij maakt als het gaat om de verschillende vormen van ontkenning. Er is natuurlijk de openlijke leugen ('het is niet gebeurd'). Of men kan er een andere interpretatie aangeven ('het is niet wat je denkt dat het was'). Ook is het zo dat men de feiten accepteert maar dan de gevolgen die daar logischerwijze uit voortvloeien ontkent ('We zijn hier niet verantwoordelijk voor'). We vragen Theo of hij dit herkent vanuit zijn ervaring met Argentinië. Uit zijn antwoord blijkt dat dit inderdaad het geval is:

'Ze zeiden natuurlijk dat het allemaal subversieven en terroristen waren waar ze mee in oorlog waren, maar hoe zat het dan met kleine vermiste kinderen? Daar kregen zij veel moeilijkheden mee. Als je dus ook de drogredenen nagaat, is dat buitengewoon onthullend. Wat mij ook is opgevallen, is dat het wel om aantallen slachtoffers gaat maar niet over namen ... de namen worden niet genoemd. Een mens krijgt pas betekenis door zijn naam en niet door een nummer. Dat vond ik ook opvallend. [...] Andere concrete dingen die de Argentijnen ontkenden waren de plaatsen van geheime detentiecentra. Die hebben we op een lijst gezet in dat rapport. Dat waren er toen 25, maar dat zijn er vermoedelijk veel meer geweest, misschien wel 200. Op die lijst stonden dus naam en locatie. Mensen werden op geheime plaatsen vastgehouden, gemarteld en verdwenen, en er is een aantal beruchte martelcentra zoals de Escuela Superior de Mecánica de la Armada. Die centra en ook de namen die daarvoor in omloop waren werden ontkend, ze zeiden: "Dat zijn misschien door terroristen ingerichte plaatsen die zij gebruikten voor hun subversieve activiteiten. Maar detentiecentra en martelkamers die van regerings- of overheidswege waren ingericht? Die bestaan niet".

Theo benadrukt verder dat: 
'In Chili werden de mensenrechtenschendingen door het regime ook ontkend, maar niet zo geraffineerd als in Argentinië. Het duurde vaak lang voordat de Argentijnen reageerden en ze hadden hun antwoorden goed voorbereid. In die periode 1980-82 had ik diverse bronnen: o.a. van Argentijnse kant (brieven/rapportages) en twee interventies (mondelinge verklaringen). Op basis van die bronnen heb ik een aantal termen opgeschreven die vrij onthullend waren als het gaat om het taalgebruik. De dingen die mij opgevallen zijn in de brieven en hun statements is dat de Argentijnse autoriteiten voortdurend benadrukten dat ze in een oorlogssituatie zaten waar terroristen buitengewoon wreed en agressief waren; het was een strijd tegen terrorisme en de subversieven. Al die aantijgingen over verdwijningen werden voortdurend betiteld als "false", "orchestrated", en "lacking in truth"; het was "defamation", lasterpraat dus. Hoe ze over het onderwerp van die verdwenen kinderen spraken was ook uitermate cynisch. Zo werd er bijvoorbeeld eerst gezegd dat het een vrouw was die vermist was, wat daarna een moeder bleek te zijn. Verder zeiden ze dat de zaken van kinderen heel complex waren. Er werd dan gezegd dat er ook rivaliteit was tussen die terroristische groeperingen onderling, die elkaar ook aanvielen en mensen lieten verdwijnen. Of ze waren omwille van die dreiging naar het buitenland gevlucht. Er werd dus als het ware een smokescreen opgetrokken.'

Volgens Theo waren de Argentijnse autoriteiten uitermate kritisch over het feit dat in de rapportages van de VN-werkgroep de detentiecentra bij naam en toenaam werden vermeld: 'Ze waren er heel giftig over dat die namen concreet in het rapport stonden.' Theo bladert door het rapport om te kunnen vertellen wat ze daar in hun reactie precies over zeiden. $\mathrm{Na}$ even gezocht te hebben leest Theo het standpunt van het regime voor:

'It must be reiterated that in the Argentine republic there has never been any secret or any clandestine places for which the authorities have responsibilities.' ... en nu komt het ... 'However, in the struggle against terrorism the forces of law and order have discovered innumerable secret cells called peoples prisons by the terrorist gangs, these cells in addition to housing civilians and soldiers many of whom were killed there were frequently used to punish and kill members of the gangs themselves. There were harsh rules for treason and desertion for their own members.'

De reactie is intrigerend want in eerste instantie ontkennen ze het bestaan van geheime detentiecentra niet. In plaats daarvan ontkennen ze dat ze voor dergelijke instanties verantwoordelijk waren. Die verantwoordelijkheid wordt uiteindelijk bij de 'terroristen' gelegd. 


\section{Vocabulaire}

Theo duikt verder in zijn aantekeningen en haalt een lange lijst met termen naar voren:

'Termen die ik heb gevonden en die vanuit het perspectief van ontkenning relevant zijn: criminal activities of terrorist organisations, resorting pitilessly to terrorism, supposed facts, orchestrated accusations, distorted image, etc. Ze gebruiken ook vaak het woord 'aggression' en ze geven tevens aan dat de terroristen en hun 'accomplices' onderling ook verdeeld waren en vochten. Andere opvallende termen zijn: campaign of defamation, false "witnesses", false "witness" testimony, insidious and totally lacking in truth, brazen and fanciful narrative, campaign of defamation clearly fomented from abroad etc. Kenmerkend is ook dat ze witness steeds tussen aanhalingstekens plaatsen. Ze hadden dus een heel arsenaal aan ontkenningstermen. In dat opzicht waren hun reacties onthullend.'

Terwijl Theo verder bladert door de rapportage van de werkgroep en nog eens naar zijn aantekeningen kijkt, vertelt hij dat het hem ook is opgevallen dat er een ontwikkeling in de reactie van het regime zit. De ontkenningsstrategie, het discours, de argumentatie verandert in de loop der tijd:

'Later kiezen ze een andere benadering door te zeggen: "het behoort tot het verleden ... het is verleden tijd". Het is ook zo dat naarmate de tijd voortschreed het aantal verdwijningen afnam. Dat kwam door internationale druk, maar ook vooral omdat de belangrijkste tegenstanders inmiddels waren geliquideerd of geëlimineerd. Zij zeiden dat dit kwam door hoe zij om zijn gegaan met de oorlog en dat die afname dus te danken was aan hun optreden. Het kwam er bijna op neer dat ze zeiden "waarom bemoeien jullie je er nog mee? deze dingen zijn voorbij”.'

Hoe cynisch bepaalde ontkenningsstrategieën kunnen zijn, blijkt ook het volgende voorbeeld dat Theo geeft:

'Je hebt de Habeas Corpus-procedure: je kunt een geval van vermissing aanbrengen bij de rechter. Het blijkt dan dat in de verschillende brieven die de Argentijnse autoriteiten naar de VN stuurden, ze zich afvroegen waarom de slachtoffers zich niet tot de rechter wendden en in plaats daarvan naar de VN waren gegaan. Dat kwam natuurlijk omdat deze mensen bij de rechter niet opschoten met hun zaak. De rechter stelde zelf geen onderzoek in maar verwees naar de regering ("we hebben een klacht ontvangen over een verdwijning, hebben jullie informatie?”). De regering zei meestal de ze geen informatie hadden en vele rechters legden zich daarbij neer.'

Het regime insinueerde dus dat de slachtoffers geen gebruikmaakten van de rechten die ze hadden en dus onrechtmatig bij de VN aanklopten. 


\section{Politics of denial}

De resultaten van de werkgroep zijn zeer onthullend en we vragen Theo hoe zo'n werkgroep te werk gaat. Wat konden zij doen, wat voor middelen hadden ze? Theo legt uit dat de specifieke context zeer bepalend is voor hoe de groep te werk gaat:

'Het is natuurlijk de context waarin dit is gebracht. Dat was een politieke, diplomatieke context. Dus de werkgroep die rapporteerde aan statenvertegenwoordigers die deel uitmaakten van de Commissie Rechten van de Mens. Dat was een intergouvernementele Statencommissie. Het heeft lang geduurd voordat de commissie overging om die werkgroep in te stellen.'

Wat de werkwijze betreft, merkt Theo het volgende op:

'De Commissie heeft gezegd dat ze direct contact wilde opnemen met Argentinië en daar ook heen wilde gaan. Dit is min of meer afgewezen. De contacten konden alleen lopen via de ambassadeur (Martinez). Hij had zich ook helemaal ingeleefd, in die positie, en zette zich op alle manieren schrap. Er liepen ook van zijn missie vreemde mensen in mijn departement rond. Zij hadden kennelijk geheime contacten met mensen om dingen te weten te komen. De inlichtingen- en veiligheidsdiensten hielden ons nauwlettend in de gaten. Dat is me wel opgevallen. Verder werden we ook niet echt financieel en logistiek goed ondersteund om het onderzoek te doen. Ik had bijvoorbeeld extra mensen nodig om dit werk te doen, maar daar waren geen financiën voor. Daar moest speciaal een besluit over worden genomen. Dat besluit werd dan genomen, maar dat werd in New York tegengewerkt. Ik had heel veel gemotiveerde jongeren die aan de zaken werkten, maar hun contracten werden opeens niet meer verlengd. Ik moest als het ware bedelen om het geld, mensen en middelen te hebben.'

Volgens Theo hadden de Argentijnen het liefst alles vertrouwelijk gehouden:

'Ja, er was ook een andere procedure, die was confidentieel, daar wilden ze alles in stoppen. Ze verweten ons als secretariaat dat wij dus allerlei dingen in die openbare procedure brachten. Mijn uitgangspunt is dat wanneer het gaat om grove schendingen van mensenrechten, het nooit een confidentiële zaak maar een publieke zaak is. Ik vind de confidentiële procedure bovendien niet effectief. De Argentijnen hadden er echter alle belang bij om het in dat kader te houden. Aanvankelijk hebben ze zich daar trouwens ook tegen verzet. Maar later gebruikten ze het om de openbare procedure te vermijden en dwarsbomen.'

We vragen of je als lid van een dergelijke werkgroep wel alles op kunt schrijven. Kun je over alles naar eigen inzicht rapporteren, ook als andere leden van de werkgroep terughoudend zijn en sommige zaken buiten een rapportage willen 
houden? Bestaan er binnen de werkgroepen vormen van denial? Kun je alles aan het papier toevertrouwen? Volgens Theo is dat in principe geen probleem, maar er is een grens: als je mensen direct in gevaar brengt, moet je dat laten meewegen.

De politieke dimensie wordt uiteindelijk nog eens goed duidelijk als we hem vragen uit hoeveel mensen de werkgroep bestond:

'Vijf leden ... Het cynische was dat degene die voorzitter was verdween. Hij was een Irakees ... de ambassadeur van Irak in Madrid. Dit was alles heel merkwaardig. Hij belde mij op een gegeven moment op met de boodschap dat hij voor consultaties was teruggeroepen naar Bagdad. Hij gaf aan dat hij wilde dat ik dat wist. Daarna hoorden we niets meer van hem en we maakten ons grote zorgen over zijn welbevinden. Ik heb dit toen aangekaart en er werd mij verteld dat op korte termijn de minister van Buitenlandse Zaken van Irak naar Genève zou komen. Een week later kreeg ik een handgeschreven briefje dat de voorzitter zich had teruggetrokken. Ik denk, maar je weet het nooit zeker hoor, dat Argentinië zich over zijn kritische rol heeft beklaagd. Ik denk ook dat ik hem heb gered door te interveniëren, want in Irak was hij zijn leven niet zeker. Hij heeft nog tevergeefs geprobeerd een vluchtelingenstatus in Nederland te krijgen. Nu woont hij in Australië.'

\section{Right to truth}

Volgens Theo is het benoemen van zaken belangrijk: 'Wat mij opvalt is dat het moeilijker is om dingen te ontkennen als namen worden genoemd.' We vragen hem waarom precies. Is dat belangrijk omdat je door weg te kijken en het niet benoemen van misstanden het regime uiteindelijk in de kaart speelt? We komen met hem te spreken over de nieuwe aanpak die hij destijds in de VN-burelen introduceerde. Man en paard werden genoemd in relatie tot mensenrechtenschendingen, dat gebeurde publiekelijk en Van Boven en zijn medewerkers stelden hun kantoren (en soms privéwoningen) open voor de slachtoffers. Wat waren zijn primaire drives hiervoor? Ging het om het publiekelijk onthullen van de waarheid of werd zijn reactie meer gevormd door de slachtoffers die hulp bij hem zochten?

'Dat laatste zeker, maar ook de wens om aan de anonimiteit te ontsnappen en de zaken meer persoonlijk en feitelijk aan de orde te krijgen. [...] Het werd voor mij te benauwd, het werd een gewetenszaak: moet ik steeds maar mooie procedurele verhalen houden of moet ik de zaak niet bij naam en toenaam noemen? Dat laatste heb ik toen gedaan. Ik kreeg toen vanuit New York het verzoek om alles wat concreet verwees naar specifieke mensenrechtenschendingen in bepaalde landen te schrappen. Ik heb daarna binnen de VN verschillende indringende en confronterende gesprekken gehad waarin werd geprobeerd om me op andere gedachten te krijgen. Ik kon dat niet doen. Ten slotte kwam als compromis uit de bus dat een aantal passages mijn opinie 
vertegenwoordigde en niet die van de Secretaris-Generaal van de VN. Een week later kreeg ik ontslag aangezegd.'

De indrukwekkende toespraak die Theo bij zijn afscheid als directeur van de divisie mensenrechten van de VN hield, wordt nog vaak aangehaald, omdat hij zich daarin onomwonden uitsprak voor de belangen van slachtoffers en het recht op waarheidsvinding. De volgende passage is kenmerkend voor zijn levenshouding: 'I've always felt that our primary duty is towards the people in whose name the United Nations Charter was written. We must speak out on matters of principle, regardless of whom we please or displease.' In ons gesprek voegt Theo daar het volgende aan toe:

'Het recht op waarheid is zowel een recht van de slachtoffers maar ook van de samenleving. Je ziet dat langzamerhand een beweging op gang komt met betrekking tot meer openheid. Je ziet ook dat het vreemd is gelopen in Argentinië. Ze hebben na de val van het regime op enig moment wetgeving aanvaard met de strekking: Punto Final ... we moeten er nu maar eens mee ophouden ... Vervolgens werd er zelfs amnestie verleend. Later is men daar weer op teruggekomen. Ook binnen de VN heeft een normatieve ontwikkeling plaatsgevonden. Teksten zijn aangenomen over verdwijningen. Ook de right to truth is inhoudelijk verankerd; het recht om te weten wat er gebeurd is. Dat recht bestaat uit drie hoofdelementen: the right to know, the right to justice, the right to reparation. Het is een recht van het slachtoffer zelf, maar ook van de samenleving, zoals ook Stan Cohen onderstreept.'

\section{Significant others}

Tot slot vragen we hem hoe hij eigenlijk in de mensenrechten is beland. Wie zijn Theo's significant others?

Vele mensen hebben mij geïnspireerd en gemotiveerd, vaak in een bijzondere context of periode, met toen nog sterke herinneringen aan de Tweede Wereldoorlog. Ik noem Bert Röling, rechter in het Tokio Tribunaal en hoogleraar in Groningen. Zijn visie op het internationale recht, reeds ontvouwd in de jaren 1950, was voor mij een ware eye-opener. Ik noem ook Arnold Tammes, die in samenspraak met het ministerie van Buitenlandse Zaken voor mij de weg plaveide in Amsterdam naar een leeropdracht over de rechten van de mens. Let wel, we hebben het hier nog wel over de jaren 1960 waarin dit allemaal nog in de kinderschoenen stond. En niet te vergeten Marga Klompé, de eerste vrouwelijke minister in Nederland, doordrongen van een diep doorleefde oecumenische gezindheid waarmee zij ook al aan de wieg stond van de geboorte van de Universele Verklaring van de Rechten van de Mens. Van het ministerie van Buitenlandse Zaken kreeg ik de ruimte om mij te ontplooien, zowel academisch als in de ambiance en de praktijk van de Verenigde Naties. Daar trof ik mensen als Frank Newman, hoogleraar te Berkeley in Californië, 
die visionair en creatief zowel mij als vele anderen inspireerde om nieuwe wegen te vinden in het doolhof van de wereldorganisatie. Tot mijn bagage behoorden ook daden en uitspraken van de Wereldraad van Kerken, waarin ik een aandeel had en die ik probeerde te herkennen in de uitgangspunten en het werk van de Verenigde Naties. Maar de 'significant others' waren voor mij niet alleen grote namen en belangrijke organisaties en instituten. Ik reken hiertoe zeer zeker collega's en kameraden met wie ik constructief en vol vertrouwen heb samen gewerkt in de Verenigde Naties, onder wie in het bijzonder mijn assistenten Bertrand Ramcharan en Thomas McCarthy. Hun steun, hun visie en hun doorzettingsvermogen waren meer dan significant. 